\title{
Pintura mural política en las calles de Haití*
}

$\mathrm{L}$ a intención de estas páginas no es elaborar un sabio discurso sobre la pintura haitiana. No soy pintor ni un estudioso del arte. En mi condición de haitiano, he vivido en $\mathrm{mi}$ país momentos exaltantes a lo largo de estos últimos siete años de oscuro y doloroso neoduvalierismo.

Mi presencia física en Haití tres meses después de la caída de Duvalier, y en los albores del corto régimen de Jean Bertrand Aristide, me ha proporcionado la oportunidad de contemplar un fenómeno político-cultural poco conocido en el resto de este mundo.

Lo he visto en sus fases de creación

* Este texto constituye un amplio comentario a las fotografias que ilustran el presente número de la revista. y elaboración. He sentido directamente, muy cerca, diría en la piel misma, el trance del artista popular, espontáneo o entrenado, nunca pagado, cuando solo o en grupo pintaba los muros de las calles de sus ciudades.

En Pétion Ville, en Port-au-Prince, en Carrefour, en Jacmel, en St. Marc, en Gonaives, por todas partes, las ciudades ruinosas, grises de polvo y mugre, entristecidas pero también encorajinadas por la violencia duvalierista y neoduvalierista, se vestían de luces con mil colores derrochados para dar vida a sueños de democracia, de justicia, de bienestar, de dignidad, de paz y de alegría.

Eran manisfestaciones que correspondían en su momento a la caida de Jean Claude Duvalier y a la sonada vic- 
toria electoral del cura presidente Titid, en las primeras elecciones libres y pacíficas, jamás habidas en 200 años de vida independiente.

El dilema para mí al hablar de la pintura política en las calles de Haití, es grande. Desarrollar un discurso político y hablar poco de estas pinturas que aún engalanan las calles de la capital, o intentar un discurso teórico sobre el arte pictórico haitiano. Debo evitar lo primero en estas páginas y de lo segundo no sería capaz.

Abordaré este fenómeno cultural con el cúmulo de información y reflexión que mi profundo afecto por los asuntos de mi país me ha permitido acumular, a través de vivencias directas y de lecturas halagadoras sobre la cultura haitiana que es mía, y me sumerge. Más que este breve escrito, servirán para ilustrar al lector algunas reproducciones en blanco y negro de fotografías a todo color tomadas en oportunidad de largos pero nunca tediosos andares por las calles de algunas ciudades. Estas caminatas, algún viaje al interior, los emprendí para acompañar a un verdadero especialista de este tema, Pablo Butcher, joven inglés que lo ha estudiado profundamente. Su inagotable material fotográfico, de calidad insuperable, ha sido expuesto en foros europeos y ha motivado doctos escritos por verdaderos especiatistas.

El tema presentado aquí constituye un fenómeno único por su orginalidad y la amplitud que adquiere en Haití. La reflexión básica alrededor de él, parte de considerar tales pinturas como una forma de expresión social, política, ideológica, artística, de un pueblo an- tillano, afroamericano. Es considerado a la vez como muestra de una mezcla cultural que llamaremos, a la manera de Depestre, criolla, en el sentido de que es el resultado de una doble influencia africana y europea.

No se puede entrar en materia sin tratar de establecer algún marco de referencia que permita su mejor entendimiento a la vez que su mayor delectación.

Se ha dicho del Caribe que su música ocupa el primer lugar en la aprehensión estética de las experiencias vividas. Hablando del Caribe en general, tal apreciación es verdadera.

La música invade, acompaña toda la vida: el recreo, el trabajo, la política, la religión, etc. El caribeño vive en música, alegre o triste, cansado o exhuberante, recreándose o peleando y protestando. Su música traspasa las fronteras de lo cotidiano, de lo local, y es conocida en ámbitos planetarios.

Pero en Haití hay otro fenómeno cultural que compite con la música para este papel: la pintura.

Malraux dijo muy atinadamente: "África encontró en los Estados Unidos de Norteamérica su genio del jazz [...]; halló su genio del color en la endeble Haití, y solamente en ella: hasta sus más pequeñas ciudades $[\ldots]$ ven a la pintura florecer en sus jardines" ( $L^{\prime}$ Intemporel).

Efectivamente, en el Caribe la pintura parece ser un fenómeno cultural haitiano. Me atrevo a sostener que en mi país esta actividad cultural es fenomenal por su vastedad:

Temática. Cubre todas las facetas de la vida haitiana. En su pintura el haitiano vive y conoce su historia, recorre 
y goza de su paisaje físico, recrea el paisaje humano que él integra, comulga en religión e ideología con otros artistas nacionales y espectadores, participa de la política, comparte a través de las imágenes la cotidianidad de la vida urbana y sobre todo rural. La lista del contenido del arte pictórico es inagotable. En otras palabras, no hay tema que no sea digno de ser pintado, de lo más concreto a lo más abstracto.

Cronológica. La tradición pictórica de esta ex colonia francesa, país de esclavos negros autoliberados, es vieja, muy antigua. Desde antes de Dewitt Peters se registran y se conservan obras importantes de pintores haitianos. Tales obras se hallan en los templos del vodú (los bumfò) (Adam Leontus, Brice), en los ámbitos de la vida laica (Numa Desroches, nacido en 1807, 3 años después de la independencia, para citar un solo ejemplo). Cuando Dewitt Peters descubre al mundo el arte pictórico haitiano, éste no tiene que ser inventado; los artistas como Hector Hyppolyte (1894), Castera Basile, Rigaud Benoît (1911), Philomé Obin (1892), ya están produciendo sin un mercado del arte que los motive.

En relación con sus actores. Los pintores haitianos son de todas las clases sociales. Estamos más acostumbrados a pensar en los artistas pintores como gente de cierta instrucción y cierto perfil social que los habilita para su dedicación artística. En Haití nuestros pintores son de todas las clases sociales, desde miembros conocidos de la burguesía hasta los humildes campesinos. Más aún, queremos insistir en que la mayoría de los in- tegrantes de este gremio son campesinos, pequeños artesanos, choferes y no solamente intelectuales educados que forman o aspiran a formar parte de una elite privilegiada consumidora de su arte. (por ejemplo, Thébaud, Duval-Carrié, Savain, Desroches, Castera, Léontus, Brice). Al formar Dewitt Peters el Centre d'Art, en 1944, las obras más importantes que reúne provienen de los bumfò, de otros sitios públicos como restaurantes tradicionales. Son también objetos rituales, domésticos, puertas, etcétera.

Es fenomenal además por su permanencia. Nunca ha desaparecido como actividad cotidiana del haitiano, con la variedad de contenido que ya hemos referido. Ni la ocupación norteamericana (1915-1934), ni los 35 años de duvalierismo y neoduvalierismo pudieron, ni pueden, matar este genio.

La pintura haitiana proyecta las esperanzas, las verdades y los misterios que iluminan íntimamente la cultura haitiana. Cuando René Despestre habla del Caribe como de una "encrucijada del planeta donde la historia ha creado focos particularmente complejos de civilización en donde lo barroco, lo picaresco, lo mágico, lo épico y lo maravilloso se penetran y se recortan mutuamente -con igual exhuberancia- en los terrenos político, social, religioso y cultural", seguramente quiere insistir en esta "criollización" del Caribe. Significa lo anterior que se transparentan las raíces africana y europea en las culturas antillanas.

En relación con la pintura haitiana, esta criollización se traduce con su 
propia voz en un profundo sentido de la nacionalidad. Fracasaron los esfuerzos de los colonizadores para cimentar sus planes de culturización colonial, intentando eliminar el pasado de los esclavos africanos. En Haití, al negarse los esclavos a imitar a los amos, surgió la nueva identidad, identidad doblemente fecundada por las raíces africana y europea. Por ejemplo, nunca el haitiano en su vida cotidiana, en su arte, tuvo miedo o vergüenza de ser negro o criollo. Así como los historiadores reportan rebeliones tempranas de los esclavos negros, negando la falsa leyenda de su resignación, en lo cultural la nación independiente hereda los rasgos fuertes de este cimarronaje social y cultural, universal y persistente.

Aimé Césaire en La tragedia del rey Christophe, hablando del monumento más grandioso de Haití, ciertamente una maravilla del planeta, dice (perdonen la mala traducción):

Yo nombro la Citadelle, símbolo de libertad de todo un pueblo. Construida por el pueblo entero [...] A este pueblo que quisieron arrodillar, le hacía falta un monumento que lo irguiera.

Siento que estas palabras pueden aplicarse sin modificación al arte pictórico haitiano. Es vehículo y símbolo de sus esperanzas, de sus verdades. de sus misterios, de su orgullo, de su nacionalismo, de su amor violento a la libertad, a la democracia.

Si se quisiera intentar una clasificación de la pintura haitiana, insistiría en buscar nuevas categorías. No es totalmente primitiva en el sentido de un arte tribal, obra de grupos sociales primitivos, marginados de la civilización contemporánea. Mucho menos es arte ingenuo, en el sentido de ser producto de artistas sofisticados que deciden imitar un estilo infantil. Tam. poco es sólo arte popular, pensando para el consumo de gente no popular; no es simplemente asimilable a una artesanía para el consumo del turista o del folclorista.

El arte pictórico haitiano tiene raíces profunclas en la historia de la formación cultural nacional, en la historia política del país, en la decisión consciente de los pintores en pro de una búsqueda por alcanzar los niveles artísticos más altos, equivalentes a lo que se ha consagrado como gran arte en cualquier parte del mundo.

Eran necesarias estas advertencias antes de decir las circunstancias de las pinturas políticas en las calles de Haití.

En 1986, y desde unos meses antes, después de la caída de Jean Claude Duvalier, se vieron en las calles de las ciudades, sobre los muros, en las bardas de madera, un sin número de pinturas hechas valientemente de noche o de día por gente común, por vecinos diríamos, y luego también por artesanos espontáneos. Dichas pinturas, verdaderas obras de arte en muchos casos, eran periódicos murales o composiciones más elaboradas que transmitían la voluntad de luchar hasta el fin contra la dictadura macoute, contra la opresión y por la democracia. En vísperas de las elecciones de diciembre de 1990, cuando va a triunfar Aristide, se repite con una intensidad mayor el mismo fenómeno. Todo intento de observación exhaustiva es 
vano. Las ciudades y las zonas rurales se cubren de estas manifestaciones espontáneas con elaborado contenido social, ideológico, político, histórico. La pintura mural de la calle es vehículo de consigna, es motor de lucha, es exacerbación de voluntad de defensa aún violenta de las conquistas revolucionarias. En ella se mezclan todos los elementos culturales del haitiano: el cristianismo, el vodú, los "loa", los héores nacionales, Aristide el nuevo líder de la nación, la consigna antimacoute, implacable pero justa.

El nivel de elaboración del trabajo artístico es tal a veces, que no se puede hablar de simples graffiti en la vía pública. El país se moviliza alrededor de estas obras, y también se deleita al igual que con su música rítmica que lo acompaña en sus manifestaciones masivas en las plazas y calles de Port-au-
Prince, del Cabo, de Jacmel y Jeremie. El pueblo haitiano pintor, analfabeto, nos descubre que tiene memoria histórica. Conoce y honra a sus héroes. El pueglo haitiano entiende de política, entiende de sociología, conoce a sus enemigos del interior y de afuera. Sabe sèr solidario, conoce la fuerza del lema nacional "La unión da fuerza". Es justo cuando exige el juicio y castigo de los torturadores, es generoso cuando lanza la consigna de su entrega a los tribunales. Sus ambiciones son de participar con su trabajo en la reconstrucción nacional y ya no quere mendigar por el mundo. Sueña con la bella patria de sus ancestros, llena de colores, de música, de amor, de esfuerzo común, de bienestar y también de paz.

Guy Duval 